\title{
Hospital Trainees' Worries, Perceived Sufficiency of Information and Reported Psychological Health During The COVID-19 Pandemic
}

\author{
Nikoo Aziminia ${ }^{\mathbf{1}^{*}}$, Aria Khani ${ }^{\mathbf{1}^{*}}$, Colette Smith ${ }^{2}$, Ameet Bakhai ${ }^{1}$, Clifford Lisk ${ }^{1}$ \\ ${ }^{1}$ Barnet Hospital, Royal Free London NHS Foundation Trust, London, United Kingdom \\ ${ }^{2}$ Institute for Global Health, University College London, London, United Kingdom \\ *Nikoo Aziminia and Aria Khani contributed equally to this paper.
}

\section{Abstract}

\section{Introduction}

The COVID-19 pandemic has been unsurpassed in clinical severity or infectivity since the 1918 Spanish influenza pandemic and continues to impact the world. During the A/H1N1 influenza pandemic, healthcare workers presented frequent concerns regarding their ownand their families' health, as well as high levels of psychological distress.

\section{Objectives}

To assess hospital trainees 'concerns, perceived sufficiency of information, behaviour and reported psychological health during the COVID-19 pandemic in the NHS

\section{Design}

Cross-sectional 39-point questionnaire study conducted in May 2020

\section{Setting}

A large NHS foundation trust in London

\section{Participants}

204 hospital trainee doctors

\section{Outcome measures}

Quantitative analysis of trainees' worries and concerns while working during the COVID-19 pandemic were assessed across 8 domains: trainee demographics; concerns and worries regarding COVID-19; perceived sufficiency of information about the COVID-19 pandemic; social distancing; use of personal protective equipment (PPE) and training in PPE; COVID-19 acquisition and risk; reported psychological health; and medical education.

\section{Results}

91.7\% looked after COVID-19 patients. 91.6\% were worried about COVID-19; the most frequent concern was that of family and friends dying from COVID-19 (74.6\%). $22.2 \%$ reported being infected with COVID-19. 6.8\% of trainees were so concerned about COVID-19 infection that they would avoid going to work. Perceived sufficiency of information about COVID-19 was moderately high. $25.9 \%$ reported that they were able to socially distance at work compared to $94.4 \%$ able to socially distance outside work. 98.2\% reported using PPE and $24.7 \%$ were confident the provided PPE protected them against infection with COVID-19. 41.9\% reported that their psychological health had been affected by their work with the commonest being anxiety (56.6\%), emotional distress $(50.9 \%)$ 
medRxiv preprint doi: https://doi.org/10.1101/2020.07.22.20158311; this version posted July 25, 2020. The copyright holder for this preprint

(which was not certified by peer review) is the author/funder, who has granted medRxiv a license to display the preprint in perpetuity.

All rights reserved. No reuse allowed without permission.

and burnout (37.7\%). 95.6\% felt it is important to have a service that provides psychological support during this pandemic and $62.5 \%$ reported they would consider using this at work.

\section{Conclusions}

A significant proportion of hospital trainees are worried about the COVID-19 pandemic with high levels of reported psychological distress. Given that almost a third would not use psychological support services at work, hospital leaders and liaison psychiatry need to explore the reasons for not wanting to use services at work and highlight the provision of psychological services provided outside work such that provided by the London deaneries professional support unit (PSU). Seeking solutions to support trainee wellbeing in addition to this, such as larger offices, adequate rest facilities and alternative methods of teaching, with their input would enable empowerment of trainees and improve their health and morale while working in a pandemic.

\section{Introduction}

In December 2019, the first reports of a cluster of cases of pneumonia of an unknown aetiology emerged from Wuhan, China.(1) As other respiratory pathogens such as SARS-CoV, MERS-CoV and influenza were excluded as causes, a novel coronavirus was subsequently identified and named SARS CoV-2, the disease caused by this being named COVID-19. The day after the genetic sequence of COVID-19 was publicly shared by China in January 2020, the first case of COVID-19 outside of China was identified in Thailand.(2) By March 2020, the WHO had declared a pandemic.(3)

As of $22^{\text {nd }}$ July 2020, there have been 14,731,563 confirmed cases of COVID-19 and 611,284 deaths reported to WHO globally.In the UK to date there have been 295,376 confirmed cases of COVID-19, the ninth highest case burden in the world and the highest in Europe, with45,312 deaths. (4) Of the UK deaths, 181 were NHS workers and 131 were social care workers, including several doctors. $(5,6)$ To date, it has been unsurpassed in terms of clinical severity and transmissibility since the 1918 Spanish influenza pandemic.(7)

A crucial element of the UK Department of Health's pandemic preparation following the H1N1 pandemic in 2009 wasa containment strategy.(8) While it is arguable how effective such a strategy would be at a point where the most populous country of the world had already succumbed to an epidemic and infection has spread to every continent, preventing healthcare systems from being overwhelmed amid increased demands has been a priority.(9) Protecting the NHS was central to the UK Government's message to the public at the onset of national lockdown(10). Inevitably, hospital practices changed significantly during the COVID-19 pandemic in order to effectively manage patients infected with SARS CoV-2 and to limit transmission.

The NHS is the $5^{\text {th }}$ biggest employer in the world, comprising of over 1 million full-time staff of whom 122,031 are doctors $(11,12)$. Hospital trainees, doctors in postgraduate training working in the hospital setting, have been on the frontline of the COVID-19 pandemic. During the previous pandemic of this scale, H1N1, hospital workers reported significant concerns regarding their own health and that of their families, with potential impact on their ability to perform their duties(13). The aim of our study was to assess the concerns of hospital trainees and the effects, perceived or otherwise, of working during this global health COVID-19 crisis on their training, their ways of working, and their physical and psychological wellbeing. 


\section{Methodology}

This cross-sectional questionnaire study was carried out between the $1^{\text {st }}$ and $31^{\text {st }}$ of May 2020 at Barnet Hospital and the Royal Free hospital (part of the Royal Free London group of hospitals within the foundation trust) United Kingdom. Barnet hospital (459 beds) and The Royal Free hospital (839 beds) are a district general hospital and a teaching hospital providing secondary and tertiary care for a population of over 900,000 people. At the time of writing this paper, 5859 patients with COVID-19 have been admitted at both hospitals with 639 deaths.

A 39-item questionnaire was developed by the authors, adapted from a previous questionnaire by Goulia et al. with permission, to assess hospital doctors' in training anxieties, worries and concerns during the pandemic; their perceived sufficiency of information concerning COVID-19; their intended behaviour; use of PPE; reported psychological health; experience of medical education; and their experience of self-isolation.(13)Two items were scored on a 9-point Likert scale from strongly agree (9) to strongly disagree (1) and one was scored on a 9-point Likert scale from extremely worried (1) to extremely unworried (9) (Figures 2 and 8). The remaining items were dichotomous.

Items were grouped into 8 domains; demographics and professional information; concerns regarding COVID-19; perceived sufficiency of information about COVID-19; social distancing; use of personal protective equipment; COVID-19 acquisition and risk; mental health and medical education. Denominators vary depending on how many trainees answered each question and the lowest number of responses to any question was 159.

\section{Recruitment}

Hospital doctors in training in all hospital departments and clinical units were asked to participate in this study via a Survey Monkey questionnaire (Appendix 1a). This was distributed by email via the administrative staff at the Postgraduate Medical Education Centre at Barnet Hospital. The email explained the purpose of the study and its aims. The first page of the questionnaire comprised further information and informed consent. All the procedures followed were in keeping with ethical standards (world medical association Helsinki declaration). The UK Health Research Authority indicated that the project did not require ethical review by an NHS/HSC or social care research ethics committee or management committee through the NHS/HSC research and development office. The project was discussed with the Royal Free Hospital R\&D office who stated that no further approvals were required. Reminder emails were sent twice, one week apart to all hospital doctors in training at Barnet Hospital and Royal Free Hospital by the administrative team at the Barnet Hospital Postgraduate Medical Education Centre.

\section{Statistical Analysis}

All statistical analyseswere performed using the Stata version 14 . Summary statistics for all variables were calculated using a complete case analysis. Questionnaire responses were stratified according to: (i) whether the trainee doctor reported or did not report any personal mental health concerns (ii) whether they were or were not redeployed during the pandemic and (iii) whether they had or had not been able to socially distance at both home and work. Chi-squared analysis, Fishers Exact and Mann-Whitney tests were performed to assess the strengths of associations. 


\section{Results}

\section{Demographics and professional information}

Of 485 hospital doctors in training sent the survey by email, 204 completed the questionnaire (42.1\%response rate). There were 123 women (60.3\%), with the most common ethnicity being Caucasian $(49.5 \%, 101)$ followed by Asian $(24.5 \%, 50)$ (Table 1$)$. The majority $(91.2 \% ; 186)$ had been looking after COVID-19 patients and $46.1 \%$ (94) were redeployed during the pandemic. Trainees were redeployed to the acute COVID-19 rota from a wide variety of areas including academic placements, dermatology, ENT, final year medical students, general practice, general surgery, histopathology, maxillofacial surgery, medical education, psychiatry, urology and virology (Appendix $1)$. 
medRxiv preprint doi: https://doi.org/10.1101/2020.07.22.20158311; this version posted July 25, 2020. The copyright holder for this preprint (which was not certified by peer review) is the author/funder, who has granted medRxiv a license to display the preprint in perpetuity.

All rights reserved. No reuse allowed without permission.

Table 1: Demographics and professional characteristics.

\begin{tabular}{|c|c|}
\hline Where do you work? * & $N(\%)$ \\
\hline Barnet Hospital & $104(51.0 \%)$ \\
\hline Royal Free Hospital & $84(41.2 \%)$ \\
\hline Chase Farm & $4(2.0 \%)$ \\
\hline GP based & $7(3.4 \%)$ \\
\hline Other & $9(4.4 \%)$ \\
\hline \multicolumn{2}{|l|}{ What is your gender? } \\
\hline Female & $123(60.3 \%)$ \\
\hline Male & $80(39.2 \%)$ \\
\hline Other/prefer not to say & $1(0.5 \%)$ \\
\hline \multicolumn{2}{|l|}{ What is your ethnicity? } \\
\hline Asian/Asian British & $50(24.5 \%)$ \\
\hline Black/Black British & $6(2.9 \%)$ \\
\hline Chinese/Chinese British & $9(4.4 \%)$ \\
\hline Middle Eastern/Middle Eastern British & $10(4.9 \%)$ \\
\hline Mixed race - other & $14(6.9 \%)$ \\
\hline Other ethnic group & $5(2.5 \%)$ \\
\hline White - British, Irish, Other & $101(49.5 \%)$ \\
\hline Prefer not to say & $9(4.4 \%)$ \\
\hline \multicolumn{2}{|l|}{ What level of practice are you currently at? } \\
\hline Core medical training Y1 & $8(3.9 \%)$ \\
\hline Foundation Y1 & $32(15.7 \%)$ \\
\hline Foundation Y2 & $30(14.7 \%)$ \\
\hline Internal medicine Y1 & $9(4.4 \%)$ \\
\hline Specialist Registrar & $76(37.3 \%)$ \\
\hline $\begin{array}{l}\text { Other (GP trainees, Surgical trainees, Emergency } \\
\text { Medicine } \\
\text { Trainees, clinical fellows and Foundation Year } 3 \text { doctors) }\end{array}$ & $49(24.0 \%)$ \\
\hline \multicolumn{2}{|l|}{ Have you been involved in looking after COVID-19 patients? } \\
\hline Yes & $186(91.2 \%)$ \\
\hline No & $18(8.8 \%)$ \\
\hline \multicolumn{2}{|l|}{ Have you been re-deployed during this COVID-19 pandemic? } \\
\hline Yes & $94(46.1 \%)$ \\
\hline No & $110(53.9 \%)$ \\
\hline
\end{tabular}

\section{Concerns and worries regarding COVID 19}

In total, 91.6\% (164/179) of trainees were worried about COVID-19 (Figure 1). The three topmost worries for trainees were the risk of families and friends dying from COVID-19, the risk of family and friends being infected with COVID-19 and the risk of being infected at work and transmitting it to family and or friends (Table 5). Trainees were less worried about themselves being infected with COVID-19, dying from COVID-19, or the consequences on their functional ability regarding family, work or social relationships in the event of being infected with COVID-19. Concerns about isolation from family and or the social environment and about a feeling of exposure due to lack of PPE were moderately high (Figure 1). Worries were higher among those reporting mental health concerns 
medRxiv preprint doi: https://doi.org/10.1101/2020.07.22.20158311; this version posted July 25, 2020. The copyright holder for this preprint (which was not certified by peer review) is the author/funder, who has granted medRxiv a license to display the preprint in perpetuity.

All rights reserved. No reuse allowed without permission.

$(97.7 \%$ vs $83.8 \%, p=0.002)$, but similar for those who were redeployed $(95.2 \%$ vs $89.4 \%, p=0.15)$ and those who were socially distanced $(95.1 \%$ vs $90.8 \%, p=0.38)$. Other trainee worries were expressed in free text responses(Appendix 2).

Figure 1: Trainee worries during the COVID-19 pandemic

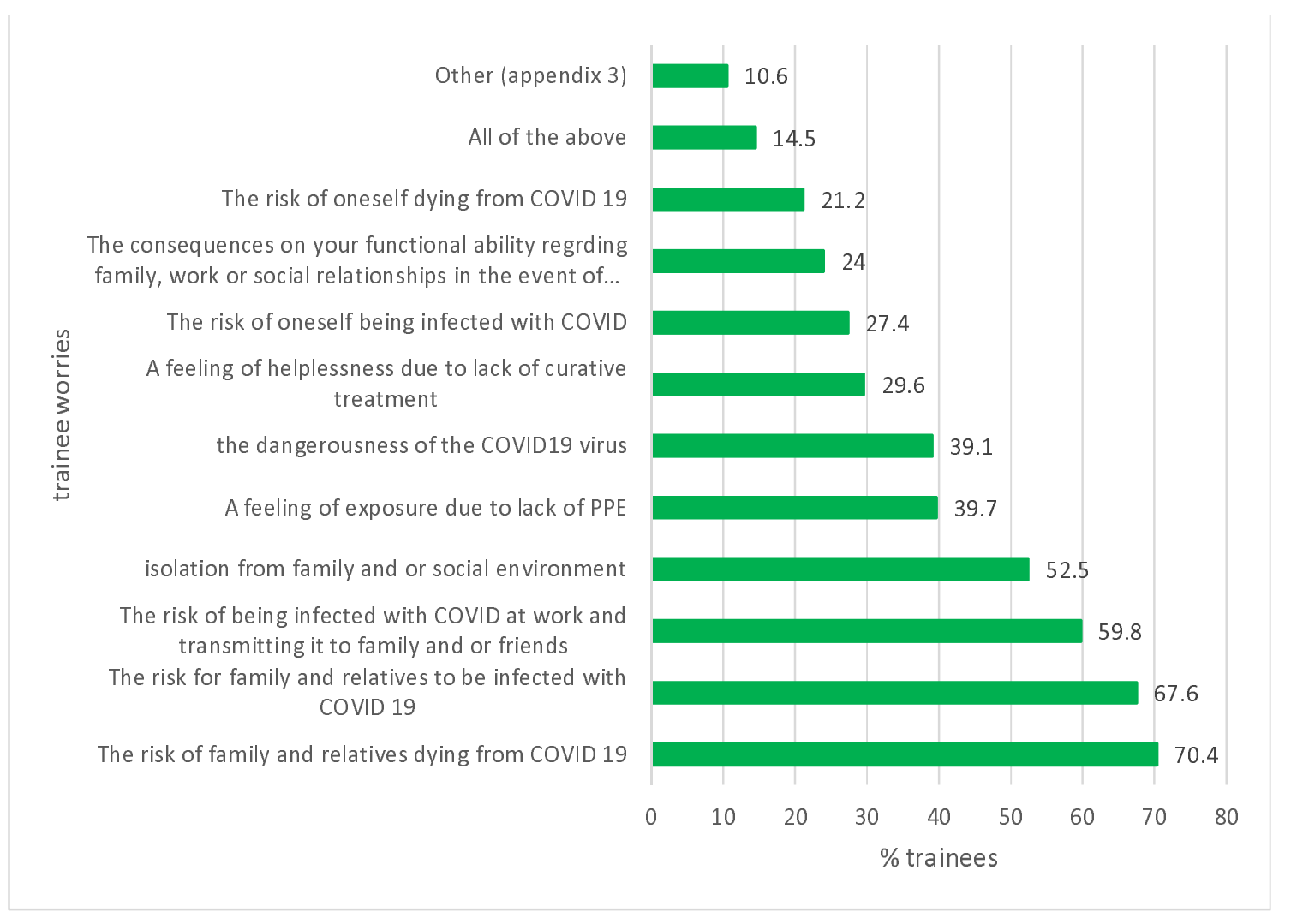

\section{Perceived sufficiency of information about the COVID-19 pandemic}

The degree of trainees' perceived sufficiency of information regarding COVID-19 symptoms, prognosis, contagion route, treatment, preventative measures, provision of information relating to the COVID-19 pandemic by the hospital, and hospital preparedness was high, with agreement ranging from $50-80 \%$ (Figure 2). $88 \%$ of trainees agreed they had received enough information about COVID-19 symptoms. $54.8 \%(158)$ of trainees agreed their hospital was well prepared for the pandemic. Perceived sufficiency of information was broadly similar between trainees with no reported mental health issues and those with reported mental health issues, those redeployed and those not redeployed and those who socially distanced and those who didn't socially distance (Tables 9-11). There was significance variation between redeployed and non-redeployed trainees in agreement with regards to the statements "I have received sufficient information about COVID-19 treatment" (Median IQR 4 vs 3, $p=0.0006$ ) and "I have received sufficient information about COVID19 preventative measures" (Median IQR $4 \mathrm{bs} 3, \mathrm{p}=0.001$ ). 
medRxiv preprint doi: https://doi.org/10.1101/2020.07.22.20158311; this version posted July 25, 2020. The copyright holder for this preprint (which was not certified by peer review) is the author/funder, who has granted medRxiv a license to display the preprint in perpetuity.

All rights reserved. No reuse allowed without permission.

Figure 2: Perceived sufficiency of information about the COVID-19 pandemic and about hospital preparedness

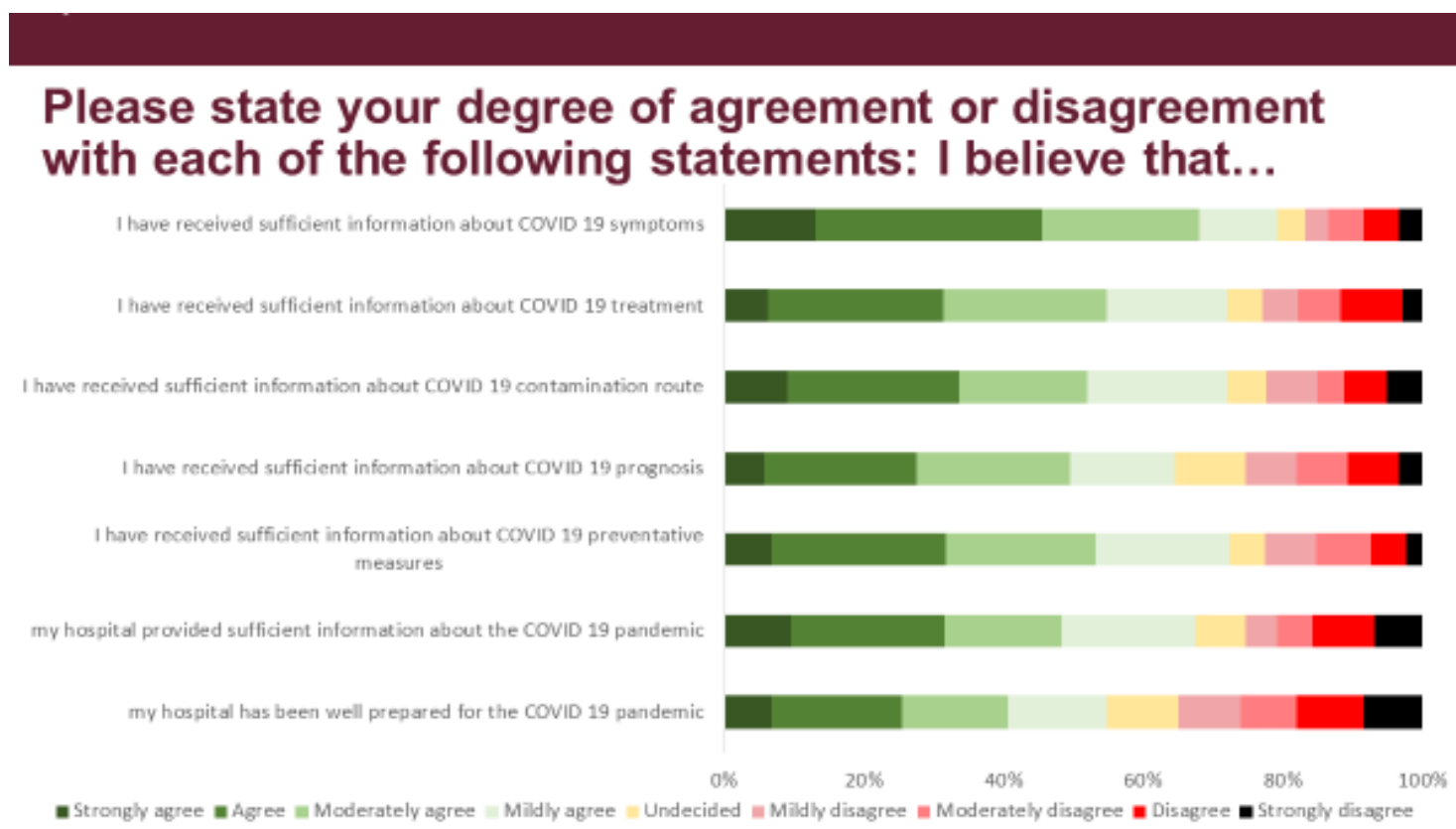

\section{Social distancing}

$25.9 \%(42)$ of trainees implemented the recommended social distancing at work whilst the majority $(94.4 \%, 152)$ implemented this outside work (Figure 3). Of those who had been redeployed, $50 \%$ did not socially distance at work compared to $33.3 \%$ who did not $(p=0.062)$. There were similar rates of worry about COVID-19 amongst trainees who did not socially distance and those who did $(90.8 \%$ vs $98.1 \% ; p=0.38$ ). $100 \%$ of trainees practising social distancing used personal protective equipment (PPE) compared with $92.9 \%$ of those who did ( $p=0.003$ ).

The commonest reasons cited for not being able to socially distance at work were ward rounds $(68.5 \%, 105)$ and board rounds due to the size of the rooms $(64.2 \%, 99)$ and due to the number of persons present $(59.9 \%, 92)$. (Figure 4). Other comments highlighting the logistical difficulties of maintaining social distancing at work were raised in free text responses (Appendix 3). The commonest suggested trainee solutions to enable social distancing at work were larger offices $(82.1 \%, 129)$, more computers $(74.1 \%, 116)$ and larger recreational spaces $(60.5 \%, 95)$. Remote ward rounds and remote teaching were indicated as solutions by $38.2 \%(60)$ and $35.7 \%(56)$ of trainees respectively. 


\section{Figure 3: Social distancing at work and outside work.}

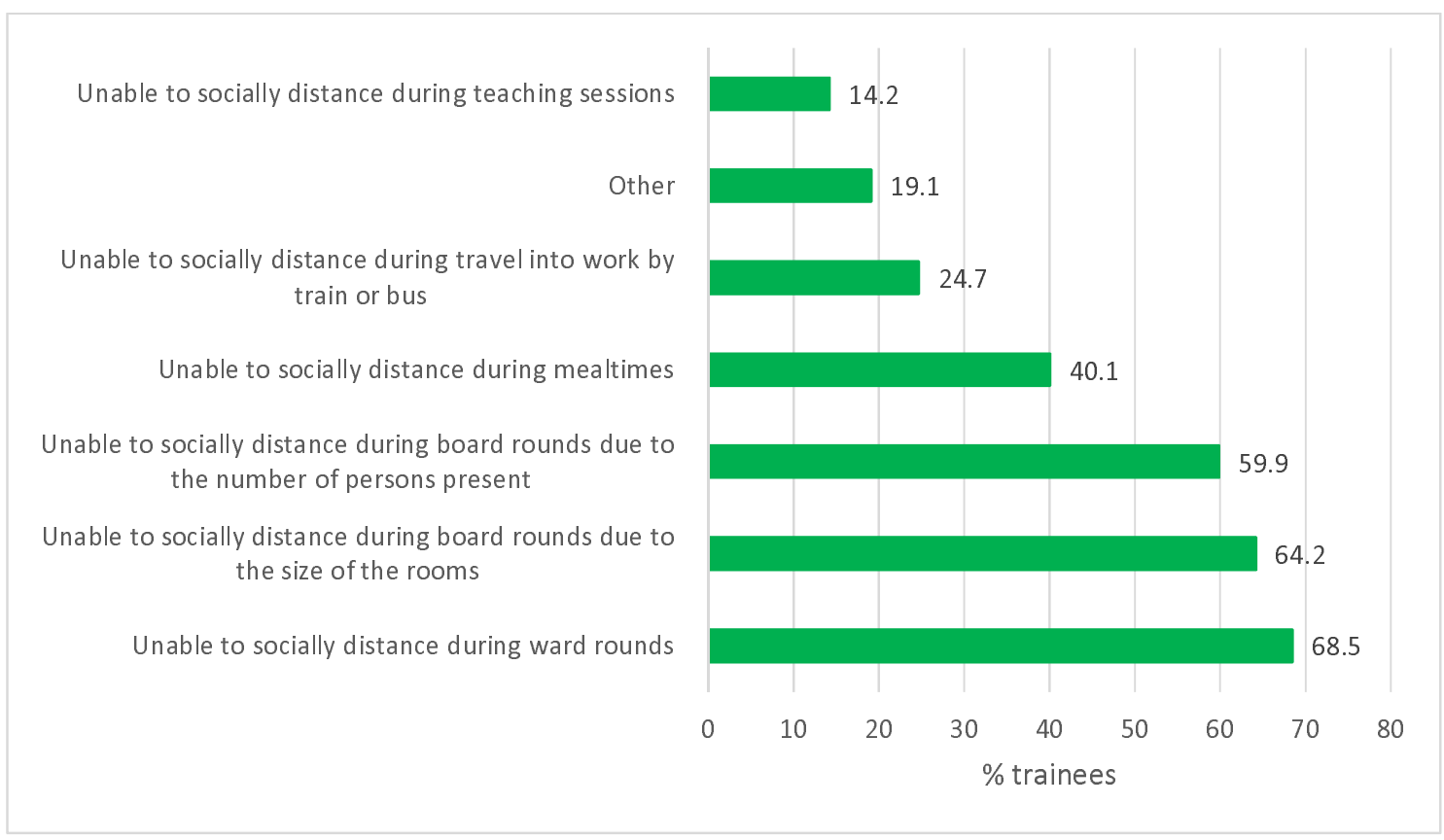

Figure 4: Reasons why trainees cannot socially distance at work ( $n=162)$

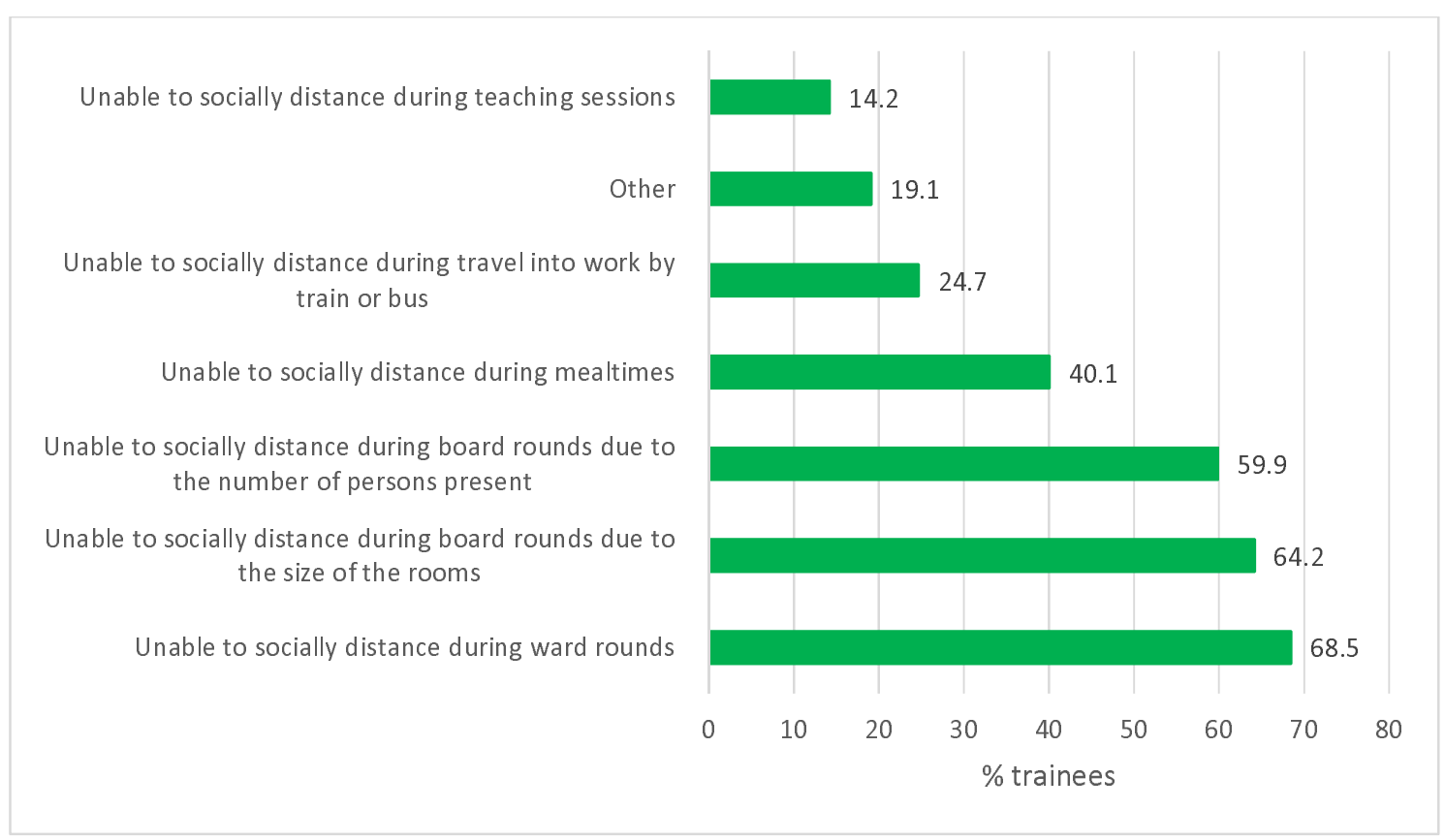


medRxiv preprint doi: https://doi.org/10.1101/2020.07.22.20158311; this version posted July 25, 2020. The copyright holder for this preprint

(which was not certified by peer review) is the author/funder, who has granted medRxiv a license to display the preprint in perpetuity.

All rights reserved. No reuse allowed without permission.

\section{Use of personal protective equipment (PPE) and training in PPE}

98.2\% (159/163) of trainees used PPE whilst caring for patients with COVID-19 and this was comparable for those with and with mental health concerns $(96.6 \%$ vs $100 \% p=0.13)$, those not redeployed and those redeployed $(97.7 \%$ vs $98.7 \%, p=0.67)$, those who socially distanced and those who did not socially distance ( $100 \%$ vs $92.9 \%, p=0.003$ ). Of these, the most commonly used PPE were disposable gloves $(93.8 \%, 152)$, disposable plastic aprons $(91.4 \%, 148)$ and scrubs $(87.7 \%, 142)$. $68.9 \%$, (111) used FFP3 masks, and46.6\% (75) used fluid resistant type IIR surgical face masks and $59 \%(95)$ used non-fluid resistant surgical masks.64\% (103) reported using face shields(Figure 6).

$70.8 \%$ (114) of trainees had training in donning and doffing. This was comparable for trainees without and with mental health concerns (76.2 vs $68.2 ; \mathrm{p}=0.25$ ), those not redeployed and those redeployed $(66.7 \%$ vs $75.7 \%, p=0.21)$ and those not socially distancing and those social distancing $(70.8 \%$ vs $70.7 \%, p=0.99)$. Of those who have had this training, $56.6 \%$ (89) agreed this training was sufficient. $24.7 \%$ (39) were confident that the PPE they were wearing at work protected them from being infected with COVID-19. 66\% (107) were confident that they were following the recommended COVID-19 infection control guidelines at work and $61.7 \%(100)$ were confident they were donning and doffing the recommended PPE correctly at work (Figure 7).

Figure 6: PPE used by trainees

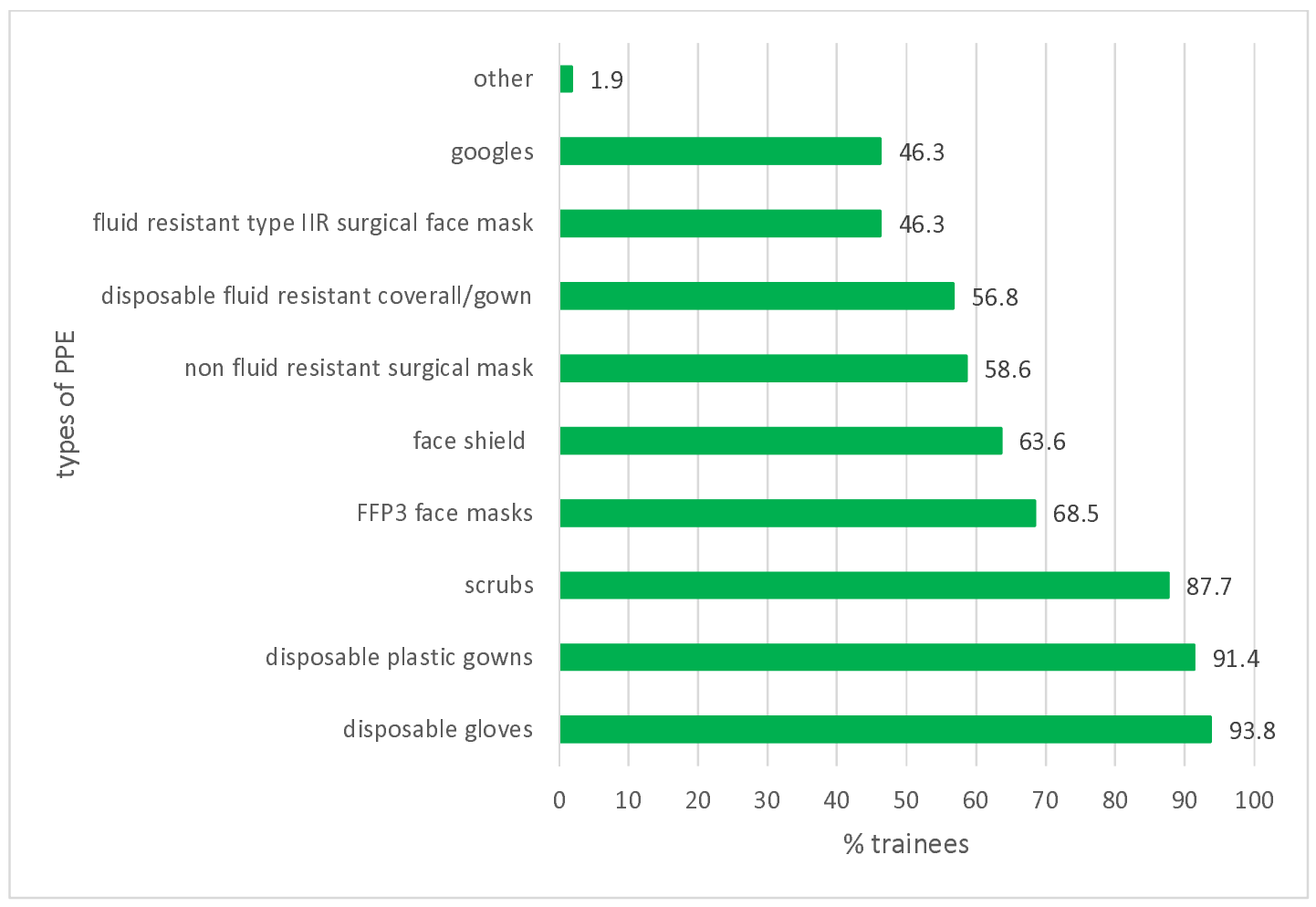


medRxiv preprint doi: https://doi.org/10.1101/2020.07.22.20158311; this version posted July 25, 2020. The copyright holder for this preprint (which was not certified by peer review) is the author/funder, who has granted medRxiv a license to display the preprint in perpetuity.

All rights reserved. No reuse allowed without permission.

Figure 7: Trainees views with regards to PPE

\section{Please indicate your degree of agreement or disagreement with the following statements}

I have had fit mask testing and training

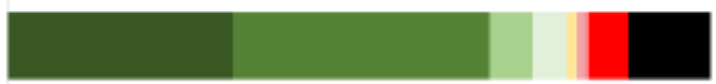

I am confident that I have been donning and doffing the recommended PPE correctly at work

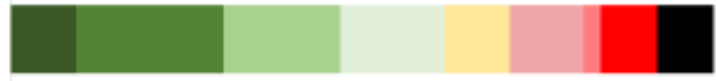

I am confident that I am following recommended COVID 19 infection control guidelines at work

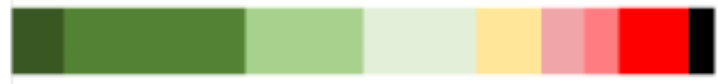

I am confident that the PPE that I am wearing at work protects me from being infected with COVID 19 at work

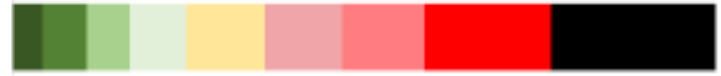

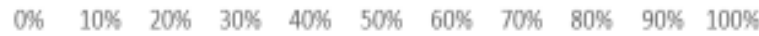

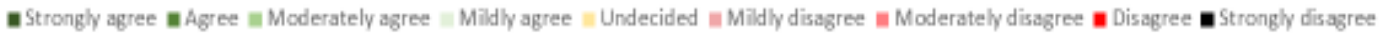

\section{COVID-19 acquisition and risk}

$22.2 \%(36)$ of trainees reporting having been infected with COVID-19. $25 \%(17)$ and $20.5 \%(18)$ of trainees with no mental health concerns and mental health concerns had been infected with COVID19 respectively ( $p=0.063$ ). $28.8 \%$ (21) of redeployed and $17.1 \%(15)$ of non-redeployed trainees had been infected with COVID-19 respectively $(p=0.15)$, whereas reported infection rates were comparable for trainees who had not socially distanced and those who had $(23.5 \%(28)$ vs $19.1 \%(8)$, $\mathrm{p}=0.64)$. Of those trainees who were unsure or reported they had not been infected $(n=132)$, $84.1 \%(110)$ perceived their risk of being infected with COVID-19 as high. The perceived risk of being infected with COVID-19 was high across all the groups; those with and without mental health concerns $83.8 \%$ (62) and $85.2 \%$ (46) respectively); those redeployed and not redeployed $(85.3 \%, 52$ and $83.1 \%, 59$ respectively); and those who did and did not socially distance $(88.8 \%, 32$ and $82.2 \%, 79$ respectively)(Figure 8 ). $6.8 \%$ (11) of trainees were so concerned about contracting COVID-19 that they would avoid going into work. Trainees with no mental health concerns $(92.5 \%, 62)$ were more likely to avoid going into work than those with mental health concerns $(71.9 \%, 64)$. 
medRxiv preprint doi: https://doi.org/10.1101/2020.07.22.20158311; this version posted July 25, 2020. The copyright holder for this preprint (which was not certified by peer review) is the author/funder, who has granted medRxiv a license to display the preprint in perpetuity.

All rights reserved. No reuse allowed without permission.

Figure 8:Trainees'perceived risk of being infected

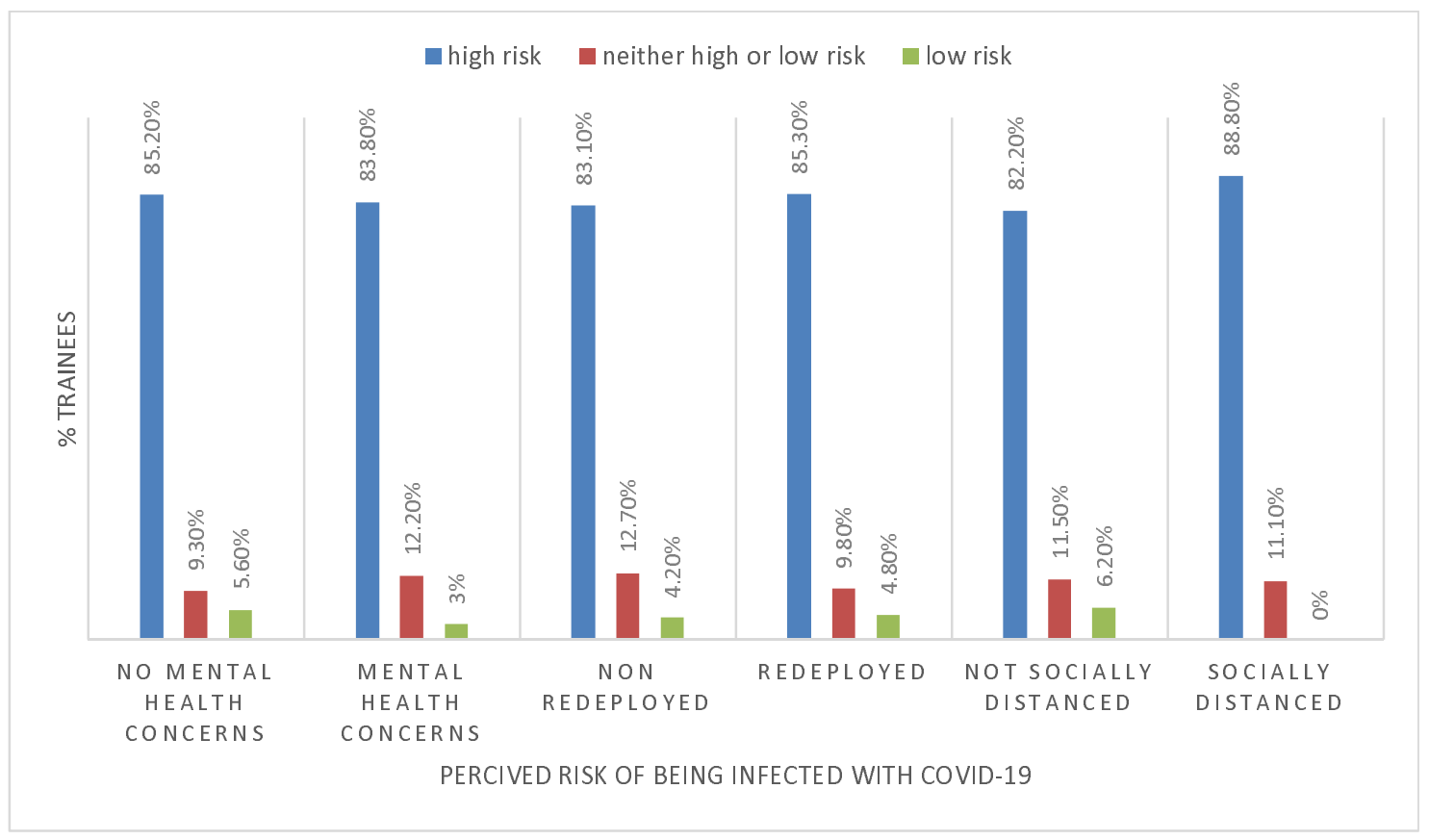

\section{Reported psychological health}

$41.9 \%(67 / 160)$ of trainees reported concerns about their psychological health. The commonest reported concerns were anxiety $(37.5 \%, 25)$, emotional distress $(33.8 \%, 23)$ and burnout $(25 \%, 17)$ (Figure 9). 56.9\% (91)trainees felt anxious about a colleague falling ill at work. 95.6\% (153) felt it was important to have psychological support services during the COVID-19 pandemic with $62.5 \%(100)$ stating they would consider using those services. $77.5 \%$ (124) of trainees were aware of the wellbeing support currently available at work; the most commonly stated avenues of support being educational and clinical supervisors ( $83.1 \%, 133$ and $76.9 \%, 123$ respectively).

Figure 9: How trainees' psychological health had been affected $(n=160)$

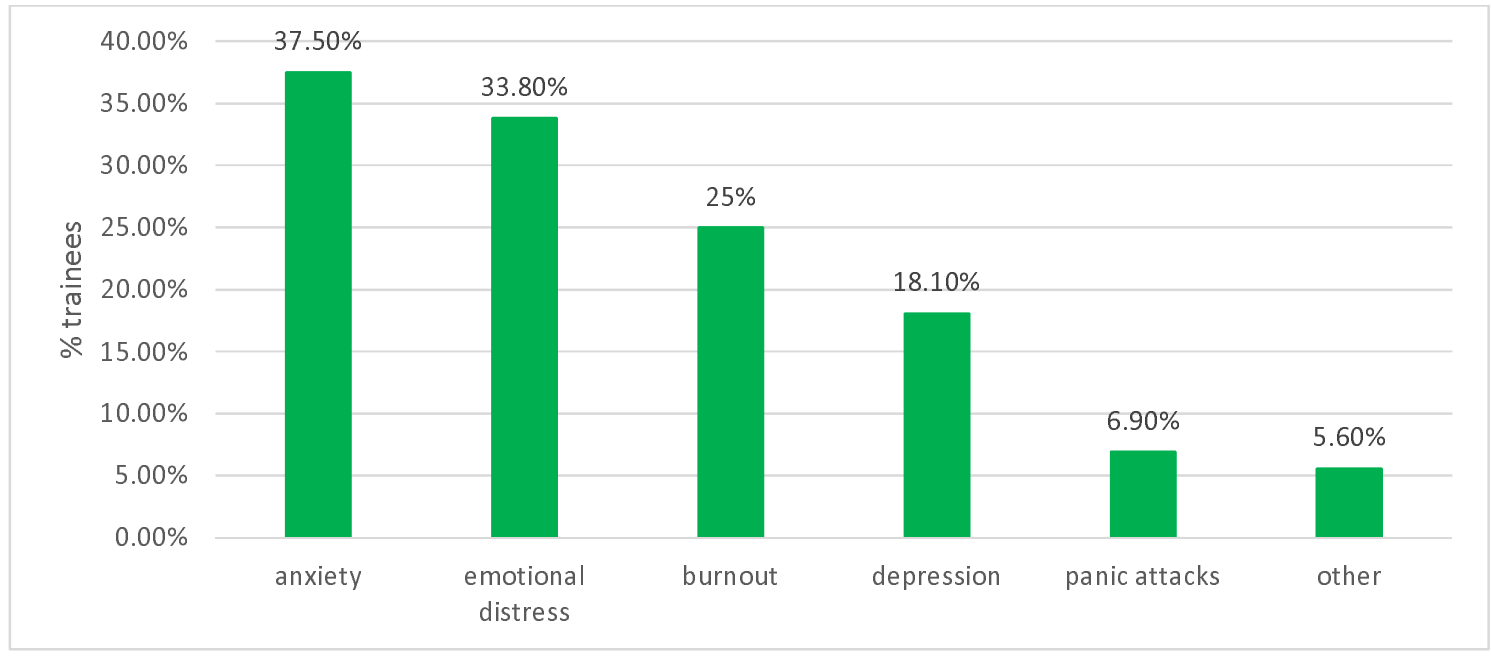




\section{Medical Education}

$73 \%(116 / 159)$ of trainees were aware the delivery of medical education had changed during the COVID-19 pandemic. The most commonly reported alternative method of delivery of medical education was Microsoft teams (Figure 10). 61\% (96) of trainees reported their commonest source of information regarding COVID-19as their employer. 53.5\% (85) of trainees received information regarding COVID-19 via television news programmes and $50.9 \%$ (81) via daily government briefings.

Figure 10: New methods of training $(n=132)$

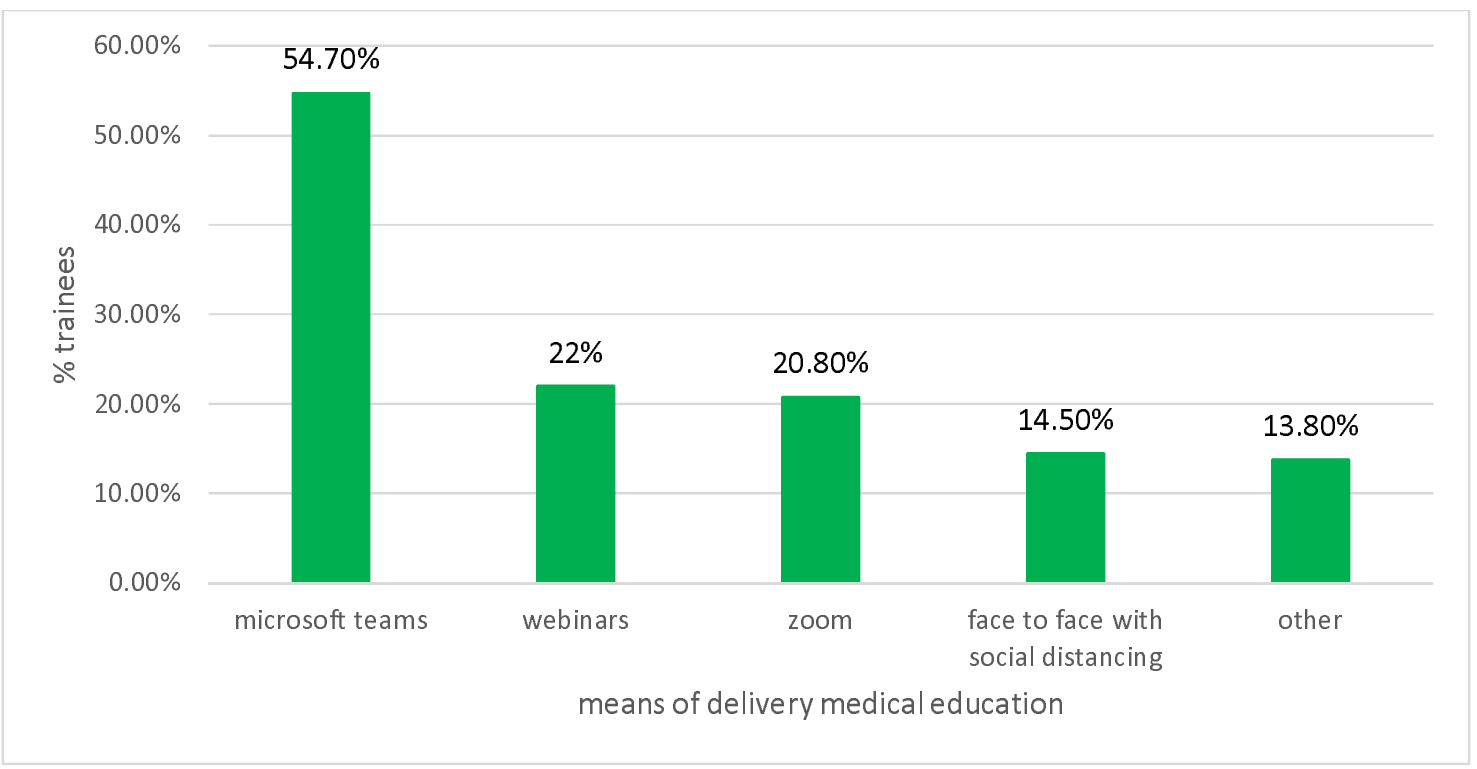

\section{Discussion}

Our study demonstrates that in May 2020 during the COVID-19 pandemic outbreak in the UK, in our hospitalmost trainees were concerned about the pandemic, with most reporting being "moderately" worried. When exploring potential reasons for this, the most recurrent concerns were for the wellbeing of family and relatives, above concerns for their own wellbeing. Due to the reality of working during the pandemic, the concern for loved ones gave rise to further concerns, namely with regards to social isolation measures andthe availability and quality of PPE.

Social isolation measures were more strictly adhered to outside of work rather than at work. This discrepancy appears to be driven by numerous factors, mainly the clinical environment itself serving as an obstacle to effective social distancing.Trainees also found it difficult to socially distances during non-clinical activities such as breaks, although many felt doing so was futile; some respondentsstated they were unable to maintain the recommended $2 \mathrm{~m}$ distance in high-risk COVID19 areas, while others questioned the evidence to support socially distancing in clinical environments. This presents a significant issue. During an infectious disease outbreak, effective social distancing is an essential public health measure that has demonstrated the potential to limit 
the spread of infection and the resultant impact on society, without the use of vaccines or antimicrobials(14).This intervention has been projected to reduce the cost in terms of human life and also of resources; by reducing the disease burden, the risk of overwhelming hospital and intensive care unit capacity would possibly be reduced and the quality of care for other medical problems would be maintained.(15)In the presence of COVID-19, a disease with transmissibility and clinical severity comparable with the 1918 influenza epidemic(7), the inability to socially distance while dispatching clinical duties is highly concerning.Solutions to this problem were explored with participants; larger spaces at work were recommended by many, namely larger doctors' offices and recreational spaces, to overcome barriers to social distancing. Investment into IT resources was another recommendation, whereby over three quarters agreed more computers would allow the minimum distance to be maintained as well as provisions for remote ward rounds, teaching, and computer software access.

Another key measure in hospitals to protect staff and limit the spread of infection is personal protective equipment (PPE). $98.2 \%$ of respondents stated they utilised PPE in their clinical practice. Of those who denied using PPE, reasons given included limited patient exposure in their clinical environment. $70.8 \%$ had received training in donning and doffing and $79.63 \%$ had undergone fit testing for masks, however there were mixed feelings about the sufficiency of their training, with $56.6 \%$ stating this was sufficient. While most respondents felt their hospital was well-prepared for the pandemic, $64.2 \%$ stated their disagreement with the notion that the PPE provided at work protected them from being infected, of whom over a third strongly disagreed. A significant area of concern voiced by participants was the issue of PPE. One participant reported having purchased their own goggles, visor, and scrubs throughout the pandemic and another suggested their infection with SARS CoV-2 was directly attributable to shortcomings in available PPE. PPE guidance as per Public Health England (PHE) has changed on a number of occasions throughout the pandemic and more recently been endorsed by the World Health Organisation (WHO).(16,17) However, subtle discrepancies exist. PHE guidance recommends the use of fluid-repellent surgical masks in clinical areas where aerosol-generating procedures are not regularly performed, while the WHO guidance recommends medical facemasks with no clarification as to the type to be used. Current evidence suggests SARS CoV-2 is spread through respiratory droplets, aerosols, direct or fomite contact, and faeco-oral transmission. While respiratory droplets tend to fall rapidly, SARS CoV-2 bio-aerosols have been shown to persist in air for at least 3 hours.(18) Coughing and sneezing can generate both droplets and aerosols, the majority of which are within the $<20 \mu \mathrm{m}$ range, while surgical facemasks may not offer protection against particles $<100 \mu \mathrm{m}$ in size.(19) One study evaluating the protection against influenza bio-aerosols offered by a range of surgical facemasks found live virus was detectable behind all masks tested(20). In addition, in a global comparison of PPE guidance, PHE guidance was unique in its recommendation of a plastic apron as body protection and on conditional use of eye protection, whereas all other guidance used in the comparison, including that of WHO, recommended a long-sleeved gown or equivalent along with eye protection in all scenarios.(21) While all respondents with direct patient contact reporting using PPE, and that provided by the Trust was in keeping with PHE guidance, it is clear from our results that the PPE trainees used was proportionate toprovisions made; $91.4 \%$ reported using plastic aprons, whereas only $56.8 \%$ reported using disposable fluid resistant gowns or coveralls, as is the WHO guidance and that of numerous countries. Interestingly, there was some heterogeneity amongst the masks used by respondents; $46.3 \%$ reported using fluid-resistant surgical masks while $58.6 \%$ reported using non-fluid resistant surgical masks. Given non-fluid resistant surgical masks were not recommended in the PPE guidance any public health body, this begs the question as to why such a discrepancy was reported and whether all surgical masks were fluid resistant. While the death of healthcare professionals during this pandemic cannot be solely attributed to potential inefficacy of PPE as per PHE guidance, this remains a controversial issue on a national level. 
Healthcare workers dying from COVID-19 is an issue that has inspired significant public concern. One of the aims of this study was to explore the physical and psychological wellbeing of hospital trainees. Almost a quarter (22.22\%) of participants confirmed they had been infected with COVID-19 and over half $(50.62 \%)$ were unsure, likely due to a lack of testing being both available (which was introduced for hospital stafffrom $30^{\text {th }}$ March 2020) and its accuracy; the sensitivity of viral RNA swabs has been shown to vary significantly depending on the site, quality and disease stage, ranging from $93 \%$ for broncho-alveolar lavage samples to $32 \%$ for throat swabs in one study(22). Of those who stated they had not been infected, $84.09 \%$ considered themselves at risk, the majority of whom deemed this as high.

41.9\% of participants reported suffering from a mental health condition relating to their work during the COVID-19 pandemic. Over a third reported anxiety, a third reported emotional distress, and other disorders including post-traumatic stress disorder and insomnia were also reported. $56.9 \%$ experienced anxiety with regards to their colleagues falling ill with COVID-19 and over three quarters of participants (79.63\%) denied they wouldavoid going to work during the pandemic. This is arguably a testament to the sense of duty engendered by the participants towards their role as doctors and towards their colleagues. Other studies of healthcare professionals during previous pandemics have found an association between the number and degree of worries with intentional absenteeism, contrary to our study's findings with this cohort(13). One reason for avoiding workcould include a sense of isolation from social networks. In a previous study during the A/H1N1 influenza pandemic, somehealthcare workers restricted their social contacts and felt isolated by their families and friends due to their work(13). Some may choose to isolate themselves due to fear of transmitting infection, as $94.4 \%$ of our participants admitted to socially distancing outside of work. In effect, social distancing may prevent a physical harm but inflict a psychological one. Aside from the potential risk posed to the lives of healthcare professionals, the notion of control may contribute to the psychological burden of working during a pandemic. The concept of control and the loss of this in complex situations may lead clinicians tofeela sense of powerlessness as they feel unable to help. This has been observed in other potentially complex clinical situations(23); it is possible the complexity of a novel infectious disease pandemic may give rise to a similar sense of helplessness, in turn leading to negative emotions and psychologicaldistress.

Formulating solutions according to specific problems may be an effective approach to ensure traineewellbeing and their ability to perform their duties optimally. Listening to the concerns of healthcare professionals and working together to reach local solutions, such as over rest facilities and equipment, may empower them and improve morale.(24)Another important facility to support trainee wellbeing is a psychological support service. While $95.6 \%$ of our participants felt psychological support services at work were important during the COVID-19 pandemic, only $62.5 \%$ stated they would consider using these at work. This highlights the need to increase awareness of psychological support services outside work, such as the London Deanery Professional Support unit.

The COVID-19 pandemic has affected almost every aspect of life for hospital trainees with medical education being no exception. Almost three quarters of respondents reported a disruption to their local and regional teaching programmes, which was resumed in alternative ways. As many sought to inform themselves independently, through discussions with consultants as well as reading academic papers, the willingness many hospital trainees participating in our study showed towards this endeavour is arguably indicative of their desire to continue their professional development even during the COVID-19 pandemic.

Our study found that the hospital trainee experience during the COVID-19 pandemic was marred by worries primarily for the wellbeing of their loved ones above their own. This was compounded by difficulties socially distancing effectively in the workplace as well as low confidence levels in the efficacy of available PPE, resulting in a large proportion of respondents feeling at risk of being 
infected with COVID-19. This in turn impacted negatively on their physical and psychological wellbeing.

There were limitations to our study which merit discussion in the interest of future work. We focused on the experience of hospital trainees within one NHS trust, while the experience of trainees in other London NHS trusts and indeed in other heavily impacted parts of the country would enable comparisons of experiences, between hospitals and regions. Indeed, our study explored solely the hospital trainee experience, however future similar studies may include other hospital professional groups to provide a comparison of experiences. As all hospital staff, namely those with direct patient contact, are at risk of infection, ensuring safety for all is a priority in future pandemic responses. Furthermore, while the disproportionate effects of COVID-19 onthose of ethnic minority background has been reported, due to the anonymity we employed in the surveys, our study did not follow through along demographic parameters to enable comparison of the white British and ethnic minority experiences and importantly on rates of infection. Additional avenues to be explored would be reasons for avoiding work as well as for not utilising psychological support services. These in turn would serve to better inform those central to pandemic preparedness planning to support hospital trainees and healthcare workers to perform their roles optimally and to safeguard their wellbeing, thereby contributing to improved clinical outcomes for our patients.

\section{Conclusion}

In conclusion, our study demonstrated that a large proportion of hospital trainees were afflicted by numerous worries while working during the COVID-19 pandemic. Coming from a range of training programmes and walks of life, the physical and psychological health of many were impacted while fulfilling their roles as doctors. Despite this, many reserved their greatest worry for their families and colleagues above themselves; a sense of duty and comradeship appeared to be important motivators.

As the first study on this scale in a major NHS Foundation Trust heavily impacted by the COVID-19 pandemic to investigate the worries and wellbeing of hospital trainees, there remain future avenues to explore. We would be keen to explore reasons for those who would avoid going to work during the COVID-19 pandemic, and the barriers to using psychological support services at work despite almost all respondents agreeing this should be available to all.

As trainees are on the frontline alongsidetheirhospital healthcare professional colleagues, they play a significant role in the fight against the COVID-19 pandemic. The adoption of an open and effective approach towards addressing hospital trainees' concerns, providing safe working conditions, effective PPE, adequate rest facilities, and psychological support are crucial to ensure their wellbeing, to minimise the costs of sickness and in some cases death, as well as to safeguard the robustness of the NHS response for future pandemics.

Key messages

- Physical and psychological health of hospital trainees impacted by working during COVID-19 pandemic

- Greatest worries regarding their families, friends and colleagues over their own wellbeing

- Low levels of confidence of PPE, in use of and ability to practice social distancing

- Engaging hospital trainees in solutions and addressing their concerns crucial for ensure trainee wellbeing and morale in future pandemics 


\section{License}

The corresponding author has the right to grant on behalf of all authors and does grant on behalf of all authors, an exclusive licence (or non-exclusive for government employees) on a worldwide basis to the BMJ Publishing Group Ltd ("BMJ"), and its Licencees to permit this article (if accepted) to be published in The BMJ's editions and any other BMJ products and to exploit all subsidiary rights, as set out in our licence.

\section{Competing interest statement}

All authors have completed the Unified Competing Interest form (available on request from the corresponding author) and declare: no support from any organisation for the submitted work; CS has received personal fees from Gilead Sciences and ViiV Healthcare for preparation of educational materials; CL has received honorariums for delivering talks at BMJ live, BMJ webinar, HC-UK 2019 conferences, and the National Anticoagulation and Thrombosis Cconference 2018; no other relationships or activities that could appear to have influenced the submitted work.

\section{Transparency declaration}

The lead authors affirm that this manuscript is an honest, accurate, and transparent account of the study being reported; that no important aspects of the study have been omitted; and that any discrepancies from the study as planned (and, if relevant, registered) have been explained.

Ethics, funding, and sponsorship statements

Ethical approval was not required for this study.

No funding was received for this study.

There were no sponsors for this study.

\section{Contributorship statement}

NA and AK contributed equally to this paper. NA and AK contributed equally to conceptualisation, planning, conduct, analysis, writing, and reporting of the work described in the article.

CS contributed to data analysis and review of the paper.

$A B$ contributed to the resources and administration of the project.

$\mathrm{CL}$ provided the overall supervision of the project as well as contributing to the conceptualisation, planning, analysis, and review of the paper.

\section{Patient and Public Involvement statement}

Patients and the public were not involved in any way in our research.

\section{Other statements}

Clinical trial registration was not required for our research. 
medRxiv preprint doi: https://doi.org/10.1101/2020.07.22.20158311; this version posted July 25, 2020. The copyright holder for this preprint (which was not certified by peer review) is the author/funder, who has granted medRxiv a license to display the preprint in perpetuity.

All rights reserved. No reuse allowed without permission.

\section{References}

1. World Health Organization. Pneumonia Of Unknown Cause [Internet]. 2020 [cited 2020 Jun 28]. Available from: https://www.who.int/csr/don/05-january-2020-pneumonia-of-unkowncause-china/en/

2. World Health Organization. Novel Coronavirus - China [Internet]. 2020 [cited 2020 Jun 28]. Available from: https://www.who.int/csr/don/12-january-2020-novel-coronavirus-china/en/

3. World Health Organization. WHO Timeline - COVID-19 [Internet]. 2020. Available from: https://www.who.int/news-room/detail/27-04-2020-who-timeline---covid-19

4. World Health Organization. WHO Coronavirus Disease (COVID-19) Dashboard [Internet]. 2020 [cited $2020 \mathrm{Jul} 22$ ]. Available from: https://covid19.who.int/

5. GP Online. Over 300 NHS and care workers dead from COVID-19 as Johnson backs "absurd" overseas levy [Internet]. 2020 [cited 2020 Jul 22]. Available from:

https://www.gponline.com/300-nhs-care-workers-dead-covid-19-johnson-backs-absurdoverseas-levy/article/1683856

6. Cook T, Kursumovic E, Lennane S. Exclusive: Deaths Of NHS Staff From Covid-19 Analysed [Internet]. Health Service Journal. 2020 [cited 2020 Jun 28]. Available from: https://www.hsj.co.uk/exclusive-deaths-of-nhs-staff-from-covid-19-analysed/7027471.article

7. Freitas ARR, Napimoga MH, Donalisio M. Assessing the severity of COVID-19. Epidemiol Serv Saude. 2020;29(2):e2020119. doi: 10.5123/S1679-49742020000200008.

8. DH Pandemic Influenza Preparedness Team. UK influenza pandemic preparedness strategy 2011. London; 2011.

9. Watkins J. Preventing a covid-19 pandemic. BMJ. 2020;368:m810.

10. GOV.UK. [Withdrawn] Coronavirus: Stay At Home, Protect The NHS, Save Lives - Web Version [Internet]. 2020 [cited 2020 Jun 28]. Available from:

https://www.gov.uk/government/publications/coronavirus-covid-19-informationleaflet/coronavirus-stay-at-home-protect-the-nhs-save-lives-web-version

11. McCarthy N. The World's Biggest Employers [Infographic] [Internet]. Forbes. 2015 [cited 2020 Jun 28]. Available from: https://www.forbes.com/sites/niallmccarthy/2015/06/23/theworlds-biggest-employers-infographic/\#5b529e87686b

12. The King's Fund. Key Facts And Figures About The NHS [Internet]. 2020 [cited 2020 Jun 28]. Available from: https://www.kingsfund.org.uk/audio-video/key-facts-figures-nhs

13. Goulia P, Mantas C, Dimitroula D, Mantis D, Hyphantis T. General hospital staff worries, perceived sufficiency of information and associated psychological distress during the A/H1N1 influenza pandemic. BMC Infectious Diseases [Internet]. BioMed Central Ltd; 2010;10(1):322. Available from: http://www.biomedcentral.com/1471-2334/10/322

14. Glass R, Glass L, Beyeler W, Min H. Targeted Social Distancing Designs for Pandemic Influenza. Emerg Infect Dis. 2006;12(11):1671-81.

15. Greenstone M, Nigam V. Does Social Distancing Matter? [Internet]. Chicago; 2020. Available 
medRxiv preprint doi: https://doi.org/10.1101/2020.07.22.20158311; this version posted July 25, 2020. The copyright holder for this preprint

(which was not certified by peer review) is the author/funder, who has granted medRxiv a license to display the preprint in perpetuity.

All rights reserved. No reuse allowed without permission.

from: https://ssrn.com/abstract=3561244

16. Public Health England. COVID-19 personal protective equipment (PPE) [Internet]. GOV.UK. 2020. Available from: https://www.gov.uk/government/publications/wuhan-novelcoronavirus-infection-prevention-and-control/covid-19-personal-protective-equipmentppe\#section-8point1

17. World Health Organisation. Modes of transmission of virus causing COVID-19: implications for IPC precaution recommendations [Internet]. WHO. 2020 [cited 2020 Jun 24]. Available from: https://www.who.int/news-room/commentaries/detail/modes-of-transmission-of-viruscausing-covid-19-implications-for-ipc-precaution-recommendations

18. van Doremalen N, Bushmaker T, Morris D, Holbrook M, Gamble A, Williamson B, et al. Aerosol and Surface Stability of SARS-CoV-2 as Compared with SARS-CoV-1. N Eng J Med. 2020;382(16):1564-7.

19. 3M. Respirators and Surgical Masks: A Comparison [Internet]. 2020 [cited 2020 Jun 24]. Available from: https://multimedia.3m.com/mws/media/9577300/respirators-and-surgicalmasks-contrast-technical-bulletin.pdf

20. HSE. Evaluating the protection afforded by surgical masks against influenza bioaerosols. 2008.

21. Thomas J, Srinivasan A, Wickramarachchi CS, Dhesi PK, Hung Y, Kamath AV. Evaluating the national PPE guidance for NHS healthcare workers during the COVID-19 pandemic. Clinical Medicine. 2020; clinmed.2020-0143.

22. Wang W, Xu Y, Gao R, Lu R, Han K, Wu G, et al. Detection of SARS-CoV-2 in Different Types of Clinical Specimens. JAMA [Internet]. 2020 May 12;323(18):1843-4. Available from:

https://doi.org/10.1001/jama.2020.3786

23. Helmich E, Diachun L, Joseph R, Ladonna K, Noeverman-Poel N, Lingard L, et al. "Oh My God, I Can"t Handle This!': Trainees' Emotional Responses to Complex Situations. Med Educ. 2018;52(2):206-15.

24. Maunder R. The experience of the 2003 SARS outbreak as a traumatic stress among frontline healthcare workers in Toronto: lessons learned. Philos Trans R Soc Lond B Biol Sci.

2004;359(1447):1117-25. 